\title{
THE TEACHER'S CONSCIENCE IS ONE OF HIS/HER PERSONALITY VALUE
}

Nowadays, during the education reform and the establishment of market relations, it remains important to preserve Ukrainian culture, the nation and its spiritual rebirth. The human conscience, in particular the teacher's conscience, is to become the basis for the implementation of these important issues. It is Important in the education of youth was, is and remains a unique figure of a teacher, which combines two powerful forces - intelligence and conscience. If the word "conscience" will be studied in the morphological structure, it will be noticed, that it has the root of "news", which means - to know, to get knowledge, to rely on its intellectual development and mind. Conscience - the main teacher's value, his/her noble quality, which combines honor, intellect, dignity, kindness, justice, decency, education of the younger generation. The teacher pays the tremendous job to develop these qualities in the students so that they become reliable, solid and steady their ethical foundation in the mature years. It is not without purpose people say, that in the young age people find or don't find their main qualities and basic values; in the mature age, they develop these qualities or don't develop, or maybe they lose them at all; in the old age they rely on their experience and acquired values throughout life, or suffer from a reproach of conscience without having an ethical support. This article deals with main moral principles in the process of assessing the students' knowledge level, which are inherent in the teacher's personality, his/her scientific views and beliefs, respect and warmth in the formation of students' humanity as a unique personality; the teacher's conscience, which opposes immoral phenomena in society and inspires students for good deeds, highlights the quality of their professional self-improvement, in particular thorough mastering of educational subjects, the deep knowledge of the nature mysteries; the student's conscience is considered; the ideals of the Goodness, the Beautiful and the Justice in each person's life are analyzed.

Keywords: conscience, teacher's personality, students, knowledge quality level, evaluation, principles, objective and biased assessment, education subjects, life.

Introduction. The problem of upbringing and ethical youth education is studied by: G. P. Vasyanovych, A. A. Marushkevych, V. D. Onishchenko. These scientists, studying the word "conscience," mean the ability to exercise moral self-control, formulate ethical responsibilities on their own, demand from themselves and from students for their implementation, because conscience measures the taken actions and it is a true guardian throughout the person's life.

Research goal and objectives. It is necessary to emphasize the basic moral principles of students' knowledge assessment inherent the teacher's personality, his/her scientific views and beliefs, respect and warmth of humanity in the students' formation as unique individuality during the research; to highlight the teacher's conscience that prevents immoral phenomena in society and inspires students for good behavior, to increase the quality of their professional self-improvement, including thorough mastery of education subjects, in-depth knowledge of the nature mysteries; consider the students' conscience; to analyze the ideals of Good, Beautiful and Just in every person's life.

Study presentation. The new interpretive dictionary of the Ukrainian language contains a thorough definition of conscience: "Conscience is awareness and a sense of moral responsibility for one's behavior, for one's actions before one selves and people, society; moral principles, views, beliefs, conscience "[6,349-350]. Therefore, the teacher, like no other, reflects those moral principles and qualities that are inherent in personality, scientific views and beliefs reproduced in the pages of pedagogical and methodological books, scientific and periodicals.

V. D. Onishchenko notes that "conscience" is a message of divine, spiritual, truly human. Conscience as the voice of God in man, as God's law, is peculiar to every person $[7,155$ - 156]. And this "God's law" the teacher provides meaningfully at lectures and seminars. His/Her mind opens up the real opportunities for achieving the triune goal in the teaching process of the young generation, namely: knowledge of the nature mysteries and their regularities, the training of higher education graduates for useful work and the upbringing of the younger generation.

Conscience determines the ability to evaluate all pedagogical methods, approaches, techniques and principles in the studying process, the measure of their usefulness and need for teachers' laborious work in gaining fundamental students' knowledge and, in particular, to keep the teacher from unwanted actions and usurped relationship to students, contrary to the principles of humanity and justice

The teacher has responsibility for the quality of student knowledge and self-determination in society. And the future of our country depends on the kind of students whichwe will prepare and educate in the conditions of economic transformations and reformation of education. Therefore, teacher's consciencepromotesthe student consolidation personality of the future specialist to put it on the bold actions to achieve the threefold purpose in studying and ideals of Goodness, Truth, Justice, Modesty, Skill, scientific and humane treatment of the environment.

G. P. Vasyanovich underlines that: "The children areon the teacher's conscience; they are the most expensive. He gives them his/her heart, knowledge, life experience. We can say that a true teacher is a teacher of conscience, spiritual wisdom, piety "[2, 250]. It is worth agreeing, because the teacher is always surrounded by children and he/she is an example of Beautiful and Justice and, therefore, on his/her conscience are children, in particular, their studying the education subjects.

Let's study the definition "on conscience," according to a new interpretative dictionary of the Ukrainian language, where it is stated, that someone is guilty of something, is morally responsible for some actions, actions. [8, 350]. As, on the teacher's conscience are children, the most important and most precious, they follow every teacher's word, his/her concession is the main criterion for measuring his/her professional training, so it is logical to note, that the students' conscience - the moral responsibility for their quality of their actions and deeds as in the educational process, and in real personal life as well.

V. O. Sukhomlynsky notes that: "Conscience is a very thin, gentle and capricious thing. If you indulge it whims and thieves, it becomes tough. We must teach children and especially adolescents to command their conscience, then it becomes the wise and noble guilty acts, the behavior of their lives "[10, 252]

It should be better to study the examples of "the capricious of conscience," which leads to inhumane attitude, ill-treatment and careless actions in the process of mastering the curriculum. "Ways of conscience" occupy an extremely important place in the youth generation upbringing and on how the lecturer will teach students to "command their conscience" depends on the success of learning, in achieving their goal. 
A well-known teacher O. M. Ostrogorsky in one of his articles cites the letter of the young F. M. Dostoevsky, who studied at the engineering school. He was disturbed by the unfair assessment given to him by the graduate exams teacher of algebra, who avenged that he had "offended" that teacher.

"Oh, how long I haven't been writing to you, my dear brother," wrote F. M. Dostoevsky, "a terrible exam... I have not been moved up into the next form. Oh, horror! Another year, a whole year of bondage. I would not worry as if I did not know that the plight, one madness prevented me... I spent so many days preparing for the exam, fell ill, lost weight, passed the exam perfectly in full force of the word volume and stayed... So, one teacher wonted... to whom I once roughed and who now had a mockery to remind me about that, explaining the reason why I was left "[8, 38 - 39]. This example clearly shows the student's punishment for his/her blame before the teacher and his/her "whims and ways of conscience."

The lecturers teach the students with different abilities and possibilities to be educated, with certain principles and approaches of mastering the education subject, and they are all combined by the knowledge of the nature mysteries and their regularities to the process of learning. On the one hand, there is a teacher with a great life experience and meaningful knowledge, and from another hand there are the students, who show their real levels of achievement.

The research has been carried out at Kyiv National University of Trade and Economics. The results are presented. To the question in the questionnaire for students: "Do you go to all classes with the same mood? $90 \%$ of the students answered, "no", not the same.

In the first place they put the teacher's intellect, his/her mental qualities and ability to think, in the second - the methodology of training, the skill of assessment the student's knowledge level, in the third - the ability not to lock up within the educational process, and continue to find the truth on the questions, in the fourth - optimistic mood, goodwill, respect for students. They are impressed by the acuteness of the teacher's mind, the obsession with science, the rich experience of life, the high pedagogical culture, the ability to speak freely and interestingly, as well as the awareness of the sense of responsibility for their actions and the high moral principles of the teacher in the education process and the peculiarities of assessing the student's knowledge level. Certainly, they pay attention to the teacher's appearance, his ability to keep up the audience and interest the students in mastering the discipline.

The inevitable joy of success, saying by the words of V.O. Suhomlynsky, when the assessment coincides with the student self-esteem. This is the success for both students and teachers. The teacher objectively carries out the pedagogical process of knowledge assessment, and students have solid knowledge of the education subject. Thus, the teacher's conscience is pure. The pure conscience is a deep awareness of private actions and comprehension, spiritual affection for own actions, high moral responsibility for the young generation, the future of our society - students.

Ivan Ogienko notes that the conscience of people is different, namely: "... government, judge, teacher, scientific" and it depends on the quality level of personality, and on "...how much they work to solve it. It is stronger in some, and in it is weaker in others. The basis is one, but it is not a single one" [5, 10-11]. Proceeding from the fact that the conscience of people is different, it is possible to expand the definition of the Metropolitan, if there is the teacher's conscience so it is possible to say, that there is the students' conscience. If students do not have a great desire for studying and mas- tering the educational material, then this is on their conscience, and the biased evaluation by the teacher is based on the teacher's conscience.

Students 'conscience makes them to treat teachers disapprovingly, who evaluate the quality of students' knowledge, focusing only on students' behavior in the learning process (lectures, seminars and practical classes). In this case, the assessment is biased, since it reflects the teacher's attitude to certain student actions that are being evaluated, and not to his/her actual acquired knowledge of the education subject. There is also a phenomenon in pedagogical practice where the students at the time of the knowledge assessment has a solid and meaningful knowledge, but the teacher subtracts his grade because he did not fulfill the order of the group, course, department. And again, the evaluation becomes unfair and serves as an instrument in the hands of the teacher to evaluate not the level of knowledge, but auxiliary factors of student behavior. Such an assessment does not reflect the actual knowledge of the teacher, but reflects only the general attitude of the teacher to the education Institute administration.

Unfair and biased evaluation negatively affects students, their attitude to studying a subject, especially in mastering a foreign language. Therefore, the teachers' conscience is spotted, if he/she uses the pedagogical process to determine the students' knowledge level for setting up the certain accounts with their, such lecturers essentially cease to be teachers, because they by their attitude "kill" the desire to study the education subjects. We'd like to note, that the evaluation is an indicator not only the student's knowledge, but also the teachers' essential work, his/her conscientious attitude tothe students and their fulfillment the professional duties. Thus, the teacher's conscience calls to work in a such way, as not to be pity for his/her actions before himself/herself, the behavior and moral qualities of his/her personality. The very important words may prove our thought: "A musician does not hit with a fist or a stick on strings, does not hit the instrument on the wall, when the strings of lyre, or the harps give a dissonance, and patiently tune them, applying all own art until it brings harmony. So in the same way, we must adapt to the mind properties, bringing mental abilities to harmony and love for the sciences, if we do not want to be stubborn from the lazy, and from the lazy are completely fools "[3, 199]. So, the teacher's conscience does not allow to "hit with a fist" on the feelings of the student's personality, does not "hit with the mark two" in the students' register, but it allows to seek methods and approaches for studying the education subjects, in particular to the student himself, to patiently assess the knowledge quality until it leads to the harmony of gaining knowledge, turning them into skills and abilities.

Aristotle, the ancient Greek scientist, stresses that conscience is a powerful potential society force, which makes possible the joint people existence, but without conscience, human life loses its worth for existence. Therefore, thanks to conscience, people balance their passions, emotions, understanding of each other and come to the "middle condition", which is perfect $[1,526]$. It is the teacher's conscience that is the "news" (message) that balances the students' emotional state and the assessment, it's the perfect indicator of the existence cost, getting a dreamed profession.

Sincere attitude to the student, as the personality of the future specialist, will help to avoid difficulties. V. O. Sukhomlynsky compares the teacher's attitude to his father's attitude toward his own child. He asks you, how would you behave when your son got into a difficult situation? It is unlikely that he would be offered to exclude him from the institute or to leave for a re-course $[11,433]$. Instead, the teach- 
er's conscience as a "potential force of society" should balance students' passions and emotions and come to a perfect "middle condition" in order to reach that comprehension", because conscience means communicate together and know together as well" [12,630].

According to Ivan Ogienko, the conscience removes good from evil and forms the sincere relationship in the studying process, and helps the student to overcome difficulties, to establish faith in his possibilities. Thus, like fathers and mothers desire the Goodness it means to block up the path for evil to the student's heart and do this not only because it is necessary to do, not only that someone watches good deeds, but on the instructions of his/her own conscience.

V. O. Sukhomlynsky notes: "How can one become the more powerful and inexhaustible judge of human actions and he conscience as well? The main thing here is this: it is necessary to protect the child's conscience from hypocrisy and obnoxiousness, to bring up children's conscience. From an early age I tried to build a relationship in a team so that, the child, stayed alone with myself, felt the power of noble people, and in the creation of good, he/she found genuine satisfaction from good deeds. The desire to do good only for the sake of praising you means that there is a spot on a clean background "[10, 251].

Thus, it is necessary to do good not for the sake of praise, but for the sake of a great vocation, a teacher, because high marks are taken by the students, it is a reward for sleepless nights spent on large stacks of books and correcting the mistakes in written assignments. And, in order not to appear a spot, we must live and work for the sake of future generation for our society, because conscience "sees" all the shortcomings and miscalculations in the teacher's work. And from the achievement of the three-pronged goal in the educational process and the specialists' success in a useful business depends on the fact that work, knowledge, skills and abilities is a perfection indicator and students' identification in the market world relations and economic transformations. The poetic lines of O. C. Pushkin highlight the convince that has the spot.

Oh! I hear: nothing can calm down us

Among the tribulations of everyday life,

It is nothing, nothing... it is only the conscience.

Yes, right, it will triumph

Over malice, over a dark lie.

But only at that spot one

One has only begun somehow

Then, it is misfortune! It is the language from the ulcer of the sea

The soul will burn, the poison pours the heart,

Like a hammer in his ears, reproaches

And it's so sad and head is in the fog,

And the boys are bloody in the eyes...

And I would run somewhere, but nowhere... it is awful!

The unfortunate one who has tarnished the conscience

[9, 213-214. The English translation is done by Iryna Zvarych].

In fact, conscience is the best counsel, especially in the moments of deeds comprehension, but not at the time of excitement: joy, embarrassment, sadness, anger, and passion, since decisions taken will require rethinking. Having made a choice, we always get the consequences of our actions and they usually depend on what we are guided by making decisions. If the teacher was guided by his/her prudence, by his/her own mind, and he/she was acting according to his/her conscience, then he/she would not be tortured by "whims and ways of conscience", but if he/she guided by the desire to revenge and was filled with anger, then the burden of the wrong choice would always be reminded of himself/herself.

G. P. Vasyanovych notes that when there is a good conscience, there must be an evil conscience $[2,256]$. And this is quite logical, since in nature there are laws of philosophy and one of them is the struggle of opposites, so there are contradictions between beings who seek to improve, change something for better. Teachers with creative ideas and thoughts encounter complicated, artificially created barriers to people with dirty ideas and evil conscience. It is these teachers who have no sense of justice, understanding, compassion and love, but the main values are their own profit and profit, they have no right to cultivate the ideals of Good and Fine, because these ideals are not known to them.

Let's refresh the PanteleimonKulish's "Black Council" historical novel, when Hetman YakimSomkov was in the prison, when Cossack Cyril Tour came to him, with the offer to free his fellow, but the commander realized that if he had agreed to get out of jail, then in his place should have been was the liberator. It was Hetman's conscience that did not allow him to hurt the pain to another person, so he refused to help, relying on his own conscience.

An extremely vivid echo is the history of May 11, 1996, when two Japanese climbers and three Nepali leaders emerged from small temporary hiding places at the edge of the northern promontory of Everest. They had to make a climb to the summit at an altitude of 8,848 meters above the sea level. The natural conditions were too complicated, but they managed to get to the summit and gain glory, despite the fact that on the way, they met semi-frozen other Indian climbers and Indians who gave signs of life and needed help, but they did not help them, because the profit and glory had been commanded by already famous climbers. Thus, climbers have won, but their conscience is spotted and they will always have in their memory the unforgettable eyes of those half-frozen climbers asking for help, and we are sure that "heroes" will remember the abandoned people throughout their lives.

A striking example is the movie produced by American director David Gay Levy, "What would you do...?" This movie describes the funny dinner which turned into a lethal test for people of different ages and layers and unknown to each other, who had been invited to that dinner, because the main task was: to hurt oneself or a stranger next to. It is he/she will win, and receives a large sum of money and life. This film perfectly demonstrates the role of conscience in the real life, because the actions on the basis of conscience have their consequences. Thus, what kind of exams the teachers will not take, as if they don't assess the students' knowledge quality, the basic exam accepts and assesses life, as a rule, it is not mistaken at all.

Conclusion. The true teacher's conscience opposes immoral phenomena and inspires him/her for good deeds, enhancement of professional activity, knowledge of the nature mysteries, the formation of ethical duties and the requirement of their fulfillment, on perfection of the ideals of the Goodness, the Beautiful, the Justice in the life of every person. The conscience measures the deeds done and always strives next to life.

\section{References}

1. Arystotel'. Politika / Sobranie sochineniy v 4 t. - T. 4. / per. s drevnehrech. / obshch. red. A. I. Dovatura. - M.: Mysl', 1983. - S. $375-644$.

2. Vasyanovych H. P. Pedahohichnaetyka: navch.-metod posibnyk. L'viv, "Norma", 2005. - 344s.

3. Komens'kiy YA. A. Vybrani pedahohichni tvory $\vee 2$ t. / Zared. A. A. Krasnovs'koho: - K.: Rad. shkola, 1940. - T. 1. - $246 \mathrm{~s}$.

4. Marushkevych A. A. Aktual'ni problemy naukovo-pedahohichnoyi spadshchyny Ivana Ohiyenka. Navch. posib. z pedahohiky. - P.: "ASMI", 2005. -312 s.

5. Mytropolyt llarion. Moyi propovidi. - Vinnipeh: V. T. "Volyn"',1973. - 115 s. 
6. Novyy tlumachnyy slovnyk ukrayins'koyi movy v 3 t. - T 3. - P - YA K.: "AKONT", 2006. - $862 \mathrm{~s}$.

7. Onyshchenko V. D. Filosofiya dukha i dukhovnoho piznannya: Khrystyyans'ko-filosofs'kanoolohiya. - L.: Lohos, 1998. - $338 \mathrm{~s}$.

8. Ostrohorskiy A. N. Sochyneniya v 3 t. - T. 3. - M.: Molodaya hvardiya, 1968. -274 s.

9. Pushkin O. S. Borys Hodunov: pereklad. M. Tereshchenka / O. S. Pushkin. Tvory: V 4 t.-T. 3. Perek. zared. L. D. Dmyterka. S. 189-286. 10. Sukhomlyns'kiy V. O. Vykhovannya vysokykh moral'nykh yakostey i norm povedinky / V. O. Sukhomlyns'kiy. Vybranitvory v 5 t. - T. 2. - K.: Rad. shkola, 1976. - S. $249-333$.

11. Sukhomlyns'kiy V. O. Bud'te dobrozychlyvymy / V. O. Sukhomlyns'kiy. Vybranitvory v 5 t. - T. 2. - K.: Rad. shkola, 1976. - S. $432-436$.

12. Feyerbakh L. Évdokenizm / L.Feerbakh. Yzbrannie fylosofskie proyzvedeniya v 2 t. - T. 1. - M.: Hospolitizdat, 1955. - S. $578-641$.

Список використаних джерел

1. Аристотель. Политика : собр. соч. В 4 т. / пер. с древнегреч. / общ. ред. А. И. Доватура. - М. : Мысль, 1983. - - Т. 4. - С. 375-644.

2. Васянович Г. П. Педагогічна етика : навч.-метод. посіб. / Г. П. Васянович. - Львів : Норма, 2005. - 344 с.

3. Коменський Я. А. Вибрані педагогічні твори. В 2 т. / Я. А. Коменський ; за ред. А. А. Красновського. - К. : Рад. шк., 1940. - Т. 1. - 246 с.

І. Зварич, д-р пед. наук, проф.

Київський національний торговельно-економічний університет, Київ, Україна

\section{СОВІСТЬ ПЕДАГОГА - ОДНА З ОСНОВНИХ ЦІННОСТЕЙ ЙОГО ОСОБИСТОСТІ}

Зазначено основні моральні принципи в процесі оцінювання рівня якості знань студентів, які притаманні особистості педагога, його наукові погляди і переконання, повага і теплота у формуванні людяності студентів як неповторної індивідуальності; висвітлено совість педагога, що протидіє аморальним явищам у суспільстві і надихає студентів на добрі вчинки, на підвищення рівня якості їхнього фахового самовдосконалення, зокрема ґрунтовного опанування навчальних предметів, глибокого пізнання таємниць природи; розглянуто совість студента; проаналізовано ідеали Добра, Прекрасного і Справедливого у житті кожної людини. Сьогодні під час реформи освіти та встановлення ринкових відносин важливо зберегти українську культуру, націю та їі духовне відродження. Людське сумління, зокрема совість вчителя, має стати основою для реалізації цих важливих питань. Важливою у вихованні молоді була, є $і$ залишається унікальна постать вчителя, що поєднує в собі дві потужні сили - розум і совість. Совість - головна цінність педагога, його благородна якість, яка поєднує в собі честь, інтелект, гідність, доброту, справедливість, порядність, виховання молодого покоління. Вчитель проводить величезну роботу, щоб розвивати ці якості у студентів, щоб вони стали надійними, міцними та стійкими у своїй етичній основі в зрілі роки. Недаремно люди кажуть, що в молодому віці люди знаходять або не знаходять свої головні якості та основні цінності; у зрілому віці вони розвивають ці якості або не розвивають, або взагалі втрачають їх; у старості вони покладаються на свій досвід і набуті цінності протягом усього життя або страждають від докору совісті, не маючи етичної підтримки.

Ключові слова: совість, особистість педагога, студенти, рівень якості знань, оцінювання, принципи, об'єктивна та необ'єктивна оцінка, навчальні предмети, життя. 